\title{
Effects of Snow Cover on Soil Heat Flux and Freeze-thaw Processes
}

\author{
Yukiyoshi IWATA*广, Masaki HAYASHI**, and Tomoyoshi HIROTA* \\ $\left(\begin{array}{c}* \text { National Agricultural Research Center for Hokkaido Region, Sinsei, Memuro, Kasai-gun, 082-0081 Japan } \\ * * \text { Department of Geoscience, University of Calgary, Calgary, Alberta, T2N 1N4 Canada }\end{array}\right)$
}

\begin{abstract}
Snow cover insulates the soil surface from cold air in winter, thereby influencing the transfer of heat and water, and the freeze-thaw processes. To evaluate the effect of snow cover on land-atmosphere energy exchange, a field study was conducted in Hokkaido, Japan. The soil froze to a depth of $20 \mathrm{~cm}$ in early December while the snow cover was relatively thin. The soil then started thawing from the bottom of the frozen layer after the snow cover reached a thickness of $70 \mathrm{~cm}$ in January. The thawing was induced by a dramatic reduction in the heat flux from the soil surface to the snow, while the upward flux from the deep $(>1 \mathrm{~m})$ soil zone provided a steady supply of heat. The magnitude of heat flux in the deep soil zone is normally much smaller than the flux in the near-surface soil exposed to large fluctuations of air temperature. However, when the soil surface was insulated by snow, the magnitude of the near-surface heat flux decreased and became comparable to that of the flux in the deeper soil zone, indicating that the effects of the latter increased after the insulation of the soil surface. Since heat flux is sensitive to thermal conductivity, accurate estimation of the thermal conductivities of soil and snow is critical for a quantitative understanding of the freeze-thaw processes.
\end{abstract}

Key words: Frozen soil, Soil freezing, Soil water, Thermal conductivity, Thermal insulation.

\section{Introduction}

Thermal insulation by snow greatly influences the soil-atmosphere energy exchange in cold regions. For example, a recent increase in the thickness of snow cover in early December caused a reduction in the frost depth in northern Japan due to insulation of the soil surface from cold air (Hirota et al., 2006). The winter soil temperature affects the condition of over-winter crops such as foliage crops and winter wheat (e.g. Noshiro and Hirashima, 1978; Shimada et al., 1993). The development of soil frost interferes with spring plowing, and the low soil temperature delays the planting of spring crops. Therefore, an evaluation of the winter soil thermal regime is essential for the understanding and proper management of agricultural soil environments in cold regions.

By affecting the freeze-thaw processes, snow cover also influences soil water movement. Substantial amounts of water move from deeper soil layers to the

Received; March 21, 2008.

Accepted; August 8, 2008.

${ }^{\dagger}$ E-mail: iwatayuk@affrc.go.jp surface layer as the soil freezes from the surface, driven by the low soil water potential at the freezing front (e.g. Gray and Granger, 1986). This upward soil water flux may reverse as the thick snow cover insulates the ground and the frozen soil layer starts warming from its bottom (Iwata and Hirota, 2005). Moreover, the thick snow cover sometimes prevents the freezing of the soil and enhances the snowmelt infiltration (Bayard et al., 2005; Iwata et al., 2008).

Previous researchers have shown that the snow-cover thickness strongly affects the rate of soil freezing (e.g. Tsuchiya, 1985; Sharratt et al., 1999; Hirota et al., 2006). The insulating effects of snow were also confirmed in forested environments by comparing the soil temperature under experimental plots, where the snow was artificially removed, and the soil temperature under control plots (Thorud and Duncan, 1972; Hardy et al., 2001; Decker et al., 2003). However, relatively little is known about the relationships between heat flux under frozen agricultural field and snow-cover thickness.

Thus, a study was conducted in an agricultural field in the Tokachi District of Hokkaido, Japan. Tokachi 
is one of the largest agricultural regions in Japan, where crop production is significantly influenced by the conditions of snow and frozen soil. Detailed field data of soil heat and water fluxes were collected, and analyzed quantitatively under various snow conditions. This paper presents an analysis of the heat flux at the top and bottom of the frozen soil layer and the rates of soil freezing and thawing. The objective of this research is to quantify the heat flux under the snow-covered field and demonstrate the effects of thick snow cover on the freeze-thaw processes and soil water dynamics.

\section{Materials and Methods}

The study was conducted from November 2002 to October 2003 at the National Agricultural Research Center for Hokkaido Region, located in the central part of the Tokachi District, Hokkaido, Japan $\left(42^{\circ} 53^{\prime} \mathrm{N}\right.$, $\left.143^{\circ} 05^{\prime} \mathrm{E}\right)$. The study site has high-permeability volcanic ash soil to a depth of $105 \mathrm{~cm}$, which is underlain a gravel layer (Iwata et al., 2008). The water table in this area is approximately $8 \mathrm{~m}$ below the ground surface (Oka, 2000). Table 1 lists the porosity and bulk density of each soil horizon determined for triplicate soil cores $(50 \mathrm{~mm}$ in length and $51 \mathrm{~mm}$ in diameter). Soil particle density was also determined for the disturbed soil samples from each horizon (Table 1). No vegetation was on the ground during the observation period.

The liquid soil water content was monitored using a water content reflectometer (WCR) (Campbell Scientific, CS615), installed horizontally at a depth of $5 \mathrm{~cm}$ and every $10 \mathrm{~cm}$ from 10 to $100 \mathrm{~cm}$ (Fig. 1). The soil temperature was monitored by thermocouples at depths of $0,2,5 \mathrm{~cm}$ and subsequently every $10 \mathrm{~cm}$ from 10 to $100 \mathrm{~cm}$. The soil temperatures between adjacent two measurement depths were estimated, based on the assumption that the soil temperature was distributed linearly between both depths. The soil was considered frozen when the temperature was below $0^{\circ} \mathrm{C}$. The snow temperature was monitored by thermocouples at 1 and $4 \mathrm{~cm}$ above the soil surface. These data were recorded at $10 \mathrm{~min}$. intervals by a data logger (Campbell Scientific, CR10X). The snowcover thickness, air temperature, and precipitation were monitored by respective sensors connected to the data logger (Iwata et al., 2008), while the snow water equivalent was measured manually once or twice a week using a $50-\mathrm{mm}$ inner diameter aluminum snow survey tube to determine the snow density.

The heat flux at the bottom of the frozen soil layer $\left(G_{f}\right)$ was estimated by:

$$
G_{f}=-\Sigma\left(C_{j} \Delta z_{j} \Delta T_{j}\right)+G_{95}
$$

where $C_{j}$ is the soil volumetric heat capacity $\left(\mathrm{J} \mathrm{m}^{-3}\right.$ $\left.\mathrm{K}^{-1}\right), \Delta z_{j}$ is the thickness (m) of the soil layer (see below), $\Delta T_{j}$ is the increase in soil temperature during a time interval, and $G_{95}$ is the heat flux $\left(\mathrm{W} \mathrm{m}^{-2}\right)$ at a depth of $95 \mathrm{~cm}$. The signs of $G_{\mathrm{f}}$ and $G_{95}$ are positive for an upward flux.

To calculate $C_{j}$, the soil profile below the frozen layer was divided into $10-\mathrm{cm}$ layers. When the frost depth was less than $10 \mathrm{~cm}$, the WCR and thermocouple at $10 \mathrm{~cm}$ represented the first layer (from the bottom of the frozen layer to a depth of $15 \mathrm{~cm}$ ), while all other layers $(15-25 \mathrm{~cm}, \ldots, 85-95 \mathrm{~cm})$ were represented by sensors installed at $20, \ldots, 90 \mathrm{~cm}$. After the frost depth had penetrated below $10 \mathrm{~cm}$, the first layer was replaced by one from the bottom of the frozen layer to a depth of $25 \mathrm{~cm}$. The $C_{j}$ was calculated by:

$$
C_{j}=c_{s} \rho_{b}+c_{w} f_{w} \rho_{w}
$$

where $c_{s}$ and $c_{w}$ are the specific heat $\left(\mathrm{J} \mathrm{kg}^{-1} \mathrm{~K}^{-1}\right)$ of soil solids and water, respectively, $\rho_{b}$ is the soil dry bulk density, and $f_{w}$ and $\rho_{w}$ are the volumetric fraction and density of water. The $c_{s}$ was estimated at 837 $\mathrm{J} \mathrm{kg}^{-1} \mathrm{~K}^{-1}$ (Hirota et al., 2001), whereas $\mathrm{c}_{w}=4217 \mathrm{~J}$ $\mathrm{kg}^{-1} \mathrm{~K}^{-1}$ and $\rho_{w}=1000 \mathrm{~kg} \mathrm{~m}^{-3}$ at $0^{\circ} \mathrm{C}$ (Dorzey, 1940;

Table 1. Soil physical properties of each soil horizon at the study site.

\begin{tabular}{cclccc}
\hline Soil layer & $\begin{array}{c}\text { Depth } \\
(\mathrm{cm})\end{array}$ & Texture & $\begin{array}{c}\text { Soil balk density } \\
\left(\mathrm{kg} \mathrm{m}^{-3}\right)\end{array}$ & $\begin{array}{c}\text { Soil particle density } \\
\left(\mathrm{kg} \mathrm{m}^{-3}\right)\end{array}$ & $\begin{array}{c}\text { Porosity } \\
\left(\mathrm{m}^{3} \mathrm{~m}^{-3}\right)\end{array}$ \\
\hline $\mathrm{A}_{\mathrm{p}}$ & $0-25$ & Silt loam & 931 & 2537 & 0.63 \\
$\mathrm{~A}$ & $25-40$ & Silt loam & 954 & 2537 & 0.62 \\
1C & $40-55$ & Clay loam & 667 & 2776 & 0.76 \\
2C1 & $55-70$ & Clay loam & 1146 & 2710 & 0.58 \\
2C2 & $70-80$ & Clay loam & 1123 & 2816 & 0.60 \\
3C & $80-105$ & Sandy loam & 1102 & 2758 & 0.60 \\
\hline
\end{tabular}


Air temp. (190 cm)

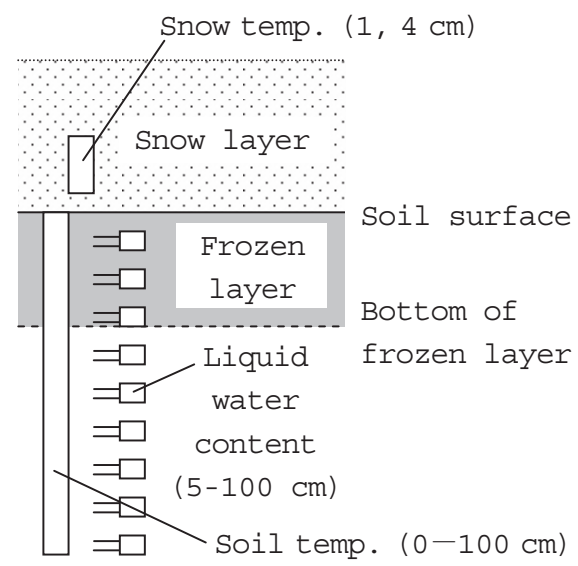

Fig. 1. Schematic diagram of the monitoring system.

Budavari, 1996). The $f_{w}$ was assumed to be equal to the volumetric water content measured by WCR. The dry bulk densities of the soil horizons (Table 1) were used to estimate $\rho_{b}$.

The $G_{95}$ was estimated by:

$$
G_{95}=-\lambda\left(\theta_{95}\right)(\Delta T / \Delta z)
$$

where $\lambda\left(\theta_{95}\right)$ is the soil thermal conductivity dependent on water content $\left(\theta_{95}\right), \Delta T$ is equal to the soil temperature at a depth of $90 \mathrm{~cm}$ minus that at a depth of $100 \mathrm{~cm}, \Delta z=10 \mathrm{~cm}$, and $\theta_{95}$ was calculated as the arithmetic mean of the soil water contents at 90 and $100 \mathrm{~cm}$. The soil thermal conductivity was estimated using the modified Johansen model (Yamazaki et al., 2003), which uses dry bulk density, quartz content, porosity, soil particle density, and water content as model input parameters. The model is essentially the same as an earlier model of Johansen (1977), described in the Appendix, except for the determination of the Kersten number $\left(K_{e}\right)$ from water saturation $\left(S_{r}\right)$ :

$$
K_{e}=0.42 S_{r}-0.05
$$

Yamazaki et al. (2003) developed this modification from the observation data of volcanic ash soils, which had much lower thermal conductivity than other mineral soil. The quartz content was estimated as $10 \%$ based on a range of 5-15\% for the volcanic ash soils reported by Yamazaki et al. (2003).

To evaluate the applicability of the above model to the study site, the thermal conductivity was also calculated based on the thermal diffusivity and volumetric heat capacity as follows. Thermal diffusivity was estimated from the amplitude of diurnal temperature fluctuation (Horton et al., 1983) in May-October 2003 for the near-surface layer $(2-5 \mathrm{~cm})$, which had a sufficiently large magnitude of fluctuation. The volumetric heat capacity was calculated from Eq. (2) using the water content measured by WCR at $5 \mathrm{~cm}$ for $f_{w}$, while thermal conductivity was given by the product of diffusivity and the volumetric heat capacity.

The same method was used to estimate the thermal conductivity of snow $\left(\lambda\left(\rho_{s}\right)\right)$ from the diurnal fluctuation of snow temperature in the snow layer between 1 and $4 \mathrm{~cm}$ above the soil surface. The volumetric heat capacity of the snow $\left(C_{s}\right)$ was estimated from:

$$
C_{s}=c_{i} \rho_{s}
$$

where $c_{i}$ is the specific heat of ice, estimated to be $2117 \mathrm{~J} \mathrm{~kg}^{-1} \mathrm{~K}^{-1}$ (Dorzey, 1940) and $\rho_{s}$ is the bulk snow density $\left(\mathrm{kg} \mathrm{m}^{-3}\right)$. Eq. (5) assumes that the snow is completely frozen with very little liquid water due to the low snow temperature $\left(<-0.3^{\circ} \mathrm{C}\right)$ during the observation period. The method was applied to temperature data from early to mid December, when the relatively thin $(<20 \mathrm{~cm})$ snow cover resulted in a sufficiently large magnitude of diurnal fluctuation.

Using the estimated $\lambda\left(\rho_{s}\right)$, the heat flux $\left(G_{s}\right)$ in the snow layer between 1 and $4 \mathrm{~cm}$ above the soil surface was calculated from:

$$
G_{s}=-\lambda\left(\rho_{s}\right)(\Delta T / \Delta z)
$$

where $\Delta T$ is equal to the snow temperature at $4 \mathrm{~cm}$ minus that at $1 \mathrm{~cm}$, and $\Delta z=3 \mathrm{~cm}$. It is assumed that $G_{s}$ indicates the flux at the middle of the layer, i.e. $2.5 \mathrm{~cm}$ above the soil surface. The heat stored in the snow between the soil surface $(0 \mathrm{~cm})$ and $2.5 \mathrm{~cm}\left(\Delta H_{\mathrm{s}}\right)$ was estimated from $C_{s}$ and the change in the snow temperature measured $1 \mathrm{~cm}$ above the soil surface. Finally the heat transferred from the soil surface to snow was calculated as the sum of $G_{s}$ and the heat stored in the $0-2.5 \mathrm{~cm}$ snow layer.

Figure 2 shows a schematic diagram of the heat balance in and above the frozen layer. The amount of heat stored (or released) in the frozen layer was calculated based on the difference between the heat fluxes at the soil surface (i.e. the top of the frozen layer) and at the bottom of the frozen layer. The difference should be equal to the sum of the latent heat associated with freezing/thawing and the heat stored as a temperature change in the frozen layer 


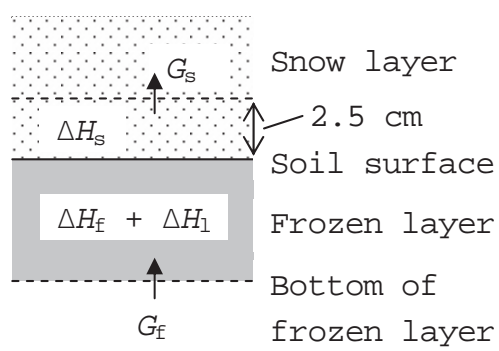

Fig. 2. Schematic diagram of the heat balance to estimate ice melting or soil water freezing in the frozen soil layer. The $G_{s}$ is the heat flux in snow at $2.5 \mathrm{~cm}$ above the soil surface, $G_{f}$ is the heat flux at the bottom of frozen layer, $\Delta H_{s}$ is the sensible heat stored in snow between the soil surface and $2.5 \mathrm{~cm}, \Delta H_{f}$ is the sensible heat stored in the frozen soil layer, and $\Delta H_{l}$ is the latent heat associated with freezing/thawing.

$\left(\Delta H_{f}\right)$. Therefore, the freezing or melting rate of soil water $\left(M, \mathrm{~m} \mathrm{~s}^{-1}\right)$ was estimated by:

$$
M=\left[G_{f}-\left(G_{s}+\Delta H_{s}\right)-\Delta H_{f}\right] /\left(\rho_{w} L_{f}\right)
$$

where $L_{f}$ is the latent heat of fusion $\left(334 \times 10^{3} \mathrm{~J} \mathrm{~kg}^{-3}\right.$; Dorzey, 1940), and positive $M$ indicates melting. The $\Delta H_{f}$ was estimated from the soil temperature at depths of $0,2,5$, and $10 \mathrm{~cm}$ and the volumetric heat capacity of the frozen layer. The volumetric heat capacity was calculated by adding the ice component $\left(c_{i} f_{i} \rho_{i}\right)$ to Eq. (2), where the liquid water fraction $\left(f_{w}\right)$ was assumed to be equal to the liquid water content measured by the WCRs. Total soil water content (ice+liquid) in each soil layer was assumed to be the same as the liquid water content just before the soil froze, and the ice fraction $\left(f_{i}\right)$ was estimated by substituting $f_{w}$ from the total soil water content. The ice density $\left(\rho_{i}\right)$ was estimated to be $931 \mathrm{~kg} \mathrm{~m}^{-3}$ at $0^{\circ} \mathrm{C}$ (Dorzey, 1940).

\section{Results}

\subsection{Air temperature, snow accumulation, soil tem-} perature and water content

The air temperature was mostly below $0^{\circ} \mathrm{C}$ from December to mid March (Fig. 3a). The frost depth increased (Fig. 3d) and soil water content between 0 - and 50-cm depth decreased (Fig. 3f) in early December. A rapid decrease in the soil water content at $5 \mathrm{~cm}$ indicates a phase change (Fig. 3f), while a gradual decrease at 20 and $50 \mathrm{~cm}$ indicates drying due to the upward soil water flux toward the freezing front. The soil temperature at $5 \mathrm{~cm}$ rose with air temperature during 13-16 December, while the frost depth decreased (Figs. 3a, 3d, and 3e). Snowfall on 17 December increased the snow-cover thickness to $>30 \mathrm{~cm}$ (Fig. 3b), while cold weather between 17 December and 4 January (Fig. 3a) caused an increase in frost depth and a decrease in 5-cm soil temperature. However, the rates of change in these variables were much slower than those observed before 17 December, as a result of the thicker snow cover.

Snow-cover thickness increased to over $70 \mathrm{~cm}$ on 4 January (Fig. 3b), after which the 5-cm soil temperature started to increase and frost depth decreased slowly until 22 March (Figs. 3d and 3e). A rapid increase in the soil water content after 22 March (Fig. 3f) indicates snowmelt infiltration (Iwata et al., 2008). The bulk density of the entire snow layer was about $300 \mathrm{~kg}$ $\mathrm{m}^{-3}$ in December, when the snow cover was relatively shallow, and during the snowmelt period in late March (Fig. 3c). The bulk snow density from January to mid March varied between 150 and $270 \mathrm{~kg} \mathrm{~m}^{-3}$.

The soil temperature at $100 \mathrm{~cm}$ gradually decreased throughout the observation period (Fig. 3e), but the changes were relatively small. The soil water content at $100 \mathrm{~cm}$ also decreased slightly until mid January, and remained virtually constant from late January to mid March (Fig. 3f).

\subsection{Thermal conductivity of soil and snow}

The soil thermal conductivity, as estimated from the analysis of diurnal temperature fluctuation, had a large degree of scatter (Fig. 4) due to several potential sources of error. The amplitude of temperature fluctuation was $4.7^{\circ} \mathrm{C}$ on average at the deeper $(5 \mathrm{~cm})$ sensor, whereas the instrumental error of the thermocouple was in the order of $0.2^{\circ} \mathrm{C}$. This translates into a potential error in thermal conductivity estimates of about 0.02 $\mathrm{W} \mathrm{m} \mathrm{m}^{-1} \mathrm{~K}^{-1}$. Other sources of error may be violation of the assumption of uniform soil water content with depth at any given time. Such violation is known to cause a substantial degree of error in the estimated thermal diffusivity (Hayashi et al., 2007), as well as the volumetric heat capacity of the soil. Despite the large degree of scatter in the experimental data (Fig. 4), the thermal conductivity for the same soil layer (2-5 $\mathrm{cm})$, as estimated by the modified Johansen model, was within the same range as the experimental data (Fig. 4). Therefore, the model was deemed appropriate for estimating the thermal conductivity of volcanic-ash soil 


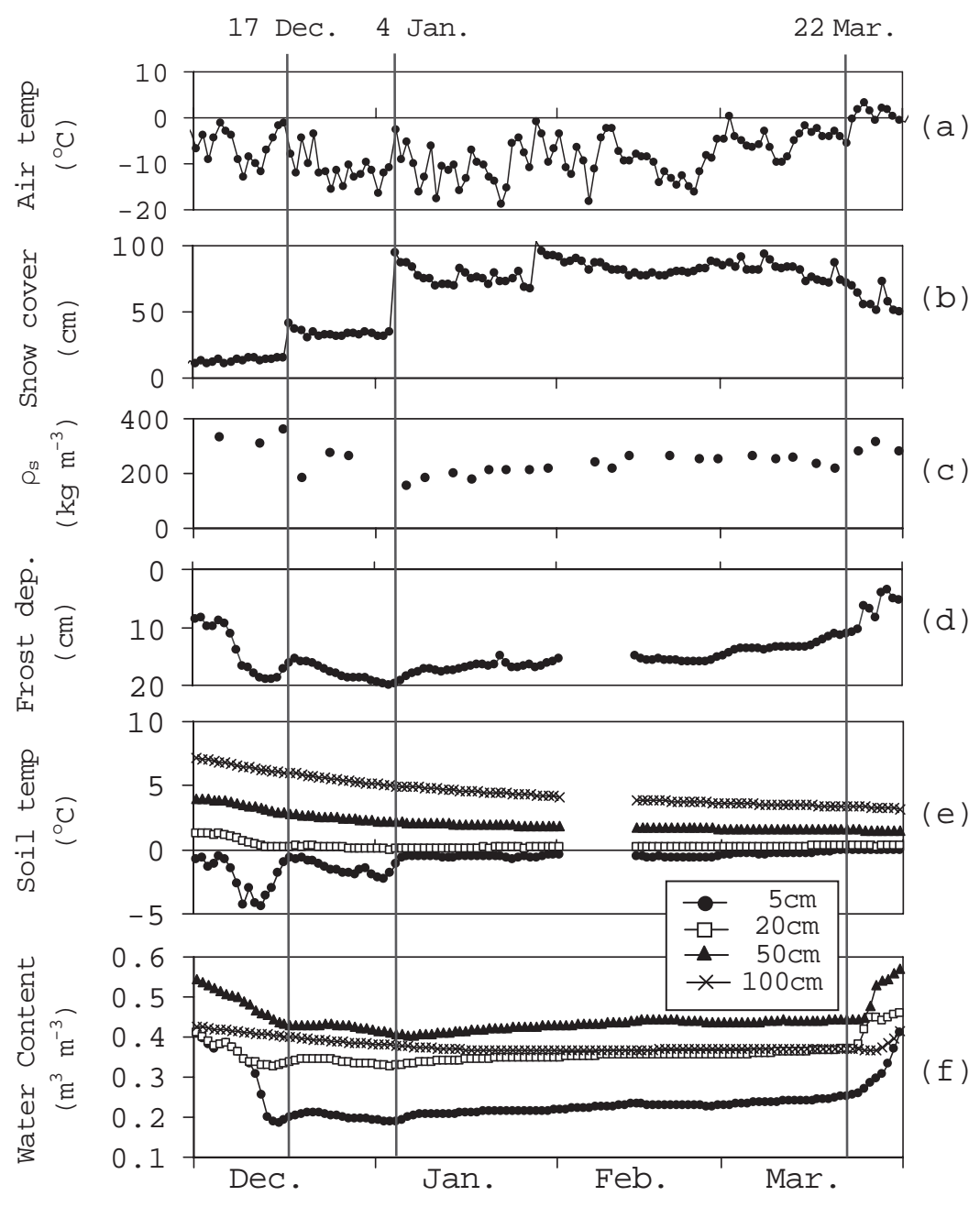

Fig. 3. Time series of a) air temperature, b) thickness of snow cover, c) snow density $\left(\rho_{\mathrm{s}}\right)$, d) frost depth, e) soil temperature, and f) soil water content from the winter of December 2002-March 2003. Snow cover and $\rho_{\text {s }}$ were measured at 09:00h. Other data are daily average. The data gaps in frost depth and soil temperature were caused by instrumental problems.

at the study site. Note that the thermal conductivity of volcanic-ash soil is generally reported to be much lower than other types of mineral soil (e.g. Kasubuchi, 1977). The root-mean-square error (RMSE) of the modified Johansen model against the experimental data (Fig. 4) was $\pm 0.06 \mathrm{~W} \mathrm{~m}^{-1} \mathrm{~K}^{-1}$. This value is used as the range of uncertainty in soil heat fluxes.

The average and standard deviation of snow thermal conductivity was $0.31 \pm 0.09 \mathrm{~W} \mathrm{~m}^{-1} \mathrm{~K}^{-1}$, as estimated from the analysis of diurnal temperature fluctuation. This is within the range of values $\left(0.1-0.4 \mathrm{~W} \mathrm{~m}^{-1} \mathrm{~K}^{-1}\right)$ reported by previous researchers (e.g. Sturm et al.,
1997). In general, the snow thermal conductivity is dependent on the bulk density of snow. However, the snow density remained high in early to mid December (300 $\mathrm{kg} \mathrm{m}^{-3}$, see Fig. 3c), and the density of the 1-4 $\mathrm{cm}$ layer was not likely to be influenced by further compaction. Therefore, $0.31 \mathrm{~W} \mathrm{~m}^{-1} \mathrm{~K}^{-1}$ was used in Eq. (6) throughout the observation period.

\subsection{Soil heat flux and water storage change}

Daily change in the total amount of soil water stored between 20 and $105 \mathrm{~cm}$ below the surface $(\Delta S)$ was calculated from the WCR data (Fig. 5). Positive values of $\Delta S$ indicate increases in the total amount of soil 


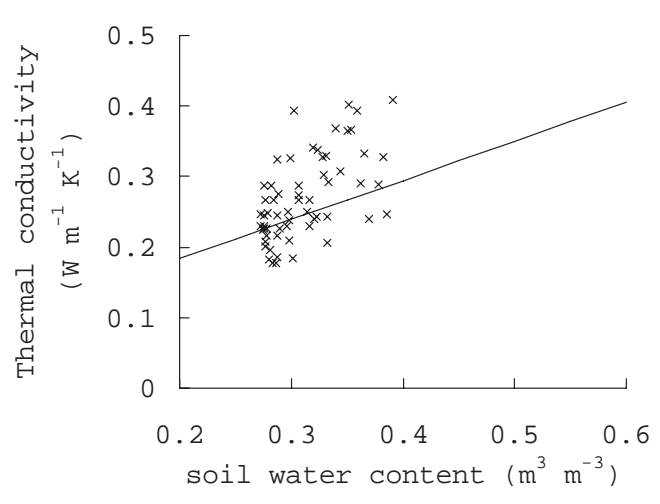

- Modified J ohansen Model

x estimated by diurnal temperature fluctuation

Fig. 4. Relationships between soil thermal conductivity and water content in the soil layer between 2 and $5 \mathrm{~cm}$ below the surface.

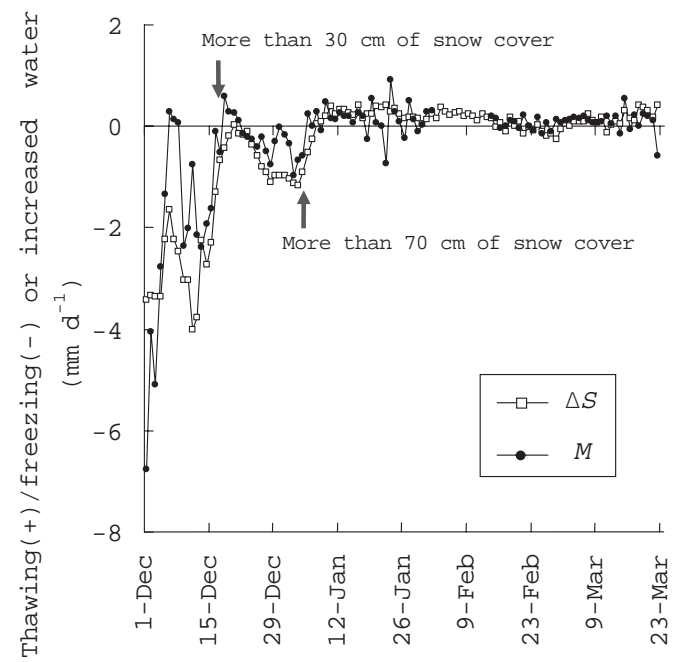

Fig. 5. Daily change in the total amount of soil water stored between 20 - and $105-\mathrm{cm}$ depths ( $\triangle \mathrm{S})$, and the rate of soil-water freezing or thawing $(M)$ in the frozen layer calculated by the heat balance method. The data gaps in $M$ in early February were caused by instrumental problems.

water. The $\Delta S$ were -4.0 to $-0.8 \mathrm{~mm} \mathrm{~d}^{-1}$ until 17 December (Fig. 5), while the snow-cover thickness was less than $15 \mathrm{~cm}$ (Fig. 3b). The snow-cover thickness increased to $>30 \mathrm{~cm}$ on 17 December, while $\Delta S$ increased to a range between -1.2 and $0 \mathrm{~mm} \mathrm{~d}^{-1}$ until 4 January (Fig. 5). Considering the fact that the air temperature remained low after 17 December (Fig. 3a), the change in the magnitude of $\Delta S$ was mainly caused by the increased thermal insulation provided by the thicker snow cover having lower bulk density (Figs. 3b and $3 \mathrm{c}$ ). The $\Delta S$ became positive after 7 January (Fig. 5), three days after the snow cover reached $>70 \mathrm{~cm}$ (Fig. 3b), indicating partial melting of the frozen soil layer and the subsequent downward percolation of melt water. The $\Delta S$ were within the range 0 and $0.4 \mathrm{~mm}$ $\mathrm{d}^{-1}$ (Fig. 5) except for a few days of negative values in late February, presumably due to refreezing in the frozen layer resulting from very low air temperature (Fig. 3a).

The rates of soil water freezing or melting $(M)$ in the frozen layer were negative before 16 December (Fig. 5) indicating freezing. The temporal pattern of $M$ was similar to that of $\Delta S$, and $M$ was mostly positive (i.e. melting) after 4 January, suggesting that soil water dynamics in the unfrozen layer were closely linked to the melting and freezing of soil water in the frozen layer above. Integrating $M$ from 1 December to 3 January indicates that $37 \pm 20 \mathrm{~mm}$ of soil water froze during this period, where the magnitude of uncertainty reflects the uncertainty in thermal conductivity estimates (see Section 3.2). During the same period, the WCRs indicated a reduction in liquid water of approximately $25 \mathrm{~mm}$ in the top $15 \mathrm{~cm}$ (i.e. the frozen layer). This is within the range $(37 \pm 20 \mathrm{~mm})$ of soil water freezing based on $M$. Since $\Delta S$ in the underlying unfrozen soil layer was negative during the same period (Fig. 5), it is likely that some liquid water from the unfrozen layer moved upward and froze in the frozen layer. However, it is difficult to quantify the rate of upward flow, partly because of the large uncertainty in $M$, and also because the soil was still draining after $120 \mathrm{~mm}$ of precipitation in November.

Integrating $M$ from 4 January to 22 March indicates that $6.7 \pm 7.7 \mathrm{~mm}$ of ice melted in the frozen soil layer under the thick snow cover, which was comparable to $7.2 \mathrm{~mm}$ given by the integration of $\Delta S$ over the same period (Fig. 5). These results suggest that the amount of liquid water generated in the frozen layer was similar to that of water added to the unfrozen layer below.

Figure 6 shows the heat fluxes at the soil surface $\left(G_{s}+\Delta H_{s}\right)$, at the bottom of the frozen layer $\left(G_{f}\right)$, and at a depth of $95 \mathrm{~cm}\left(G_{95}\right)$. The heat flux at the soil surface was within the range 2 to $15 \mathrm{~W} \mathrm{~m}^{-2}$ when the snow-cover thickness was less than $15 \mathrm{~cm}$ before 17 December (Fig. 3b), within the range 1 to 


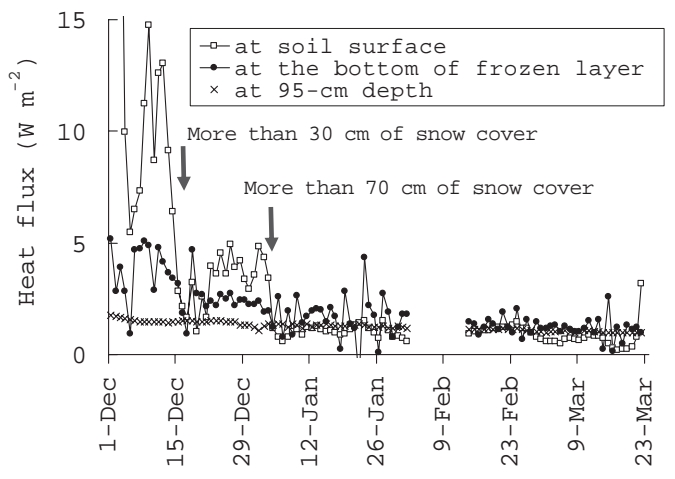

Fig. 6. Time series of heat fluxes at the soil surface, the bottom of frozen layer, and the depth of 95 $\mathrm{cm}$.

$5 \mathrm{~W} \mathrm{~m}^{-2}$ when the snow cover was more than 30 $\mathrm{cm}$ thick between 17 December and 4 January, and approximately $1 \mathrm{~W} \mathrm{~m}^{-2}$ when the snow-cover thickness was more than $70 \mathrm{~cm}$ between 4 January and 22 March. The heat flux at the bottom of the frozen layer was also decreasing as the snow-cover thickness rose, although the rate of decline was smaller than that at the soil surface. Heat flux at a depth of $95 \mathrm{~cm}$ was almost constant, and became comparable to or greater than that near the soil surface after 4 January.

\section{Discussion}

From the above, it is clear that the ice in the frozen soil layer melted after 4 January due to the upward heat flux from the underlying unfrozen layer. The magnitude of heat flux in the deep soil zone is normally much smaller than the flux in the near-surface soil exposed to large fluctuations of air temperature (e.g. Hirota et al., 2001). However, when the magnitude of surface flux is significantly reduced by the thick snow cover, the flux from the deeper $(>1 \mathrm{~m})$ soil layer is an important source of heat for melting ice in the frozen soil layer (Fig. 6).

The freezing and melting of soil water in the frozen layer affects the dynamics of soil water in the underlying unfrozen layer, while freezing and melting is strongly influenced by heat fluxes at the soil surface and at the bottom of the frozen layer. Therefore, accurate estimation of the thermal conductivities of snow and soil is a prerequisite to quantifying the soil water dynamics under thick snow cover.

\section{Conclusions}

A detailed field study was conducted to quantify the heat flux under the snow-covered field and demonstrate the effects of thick snow cover on the freeze-thaw processes and the associated soil water dynamics. A heat balance calculation showed that the soil water started melting in the frozen layer after the snow cover thickness reached $70 \mathrm{~cm}$. This was consistent with the increase in water content in the underlying unfrozen soil, indicating percolation of the melt water from the frozen layer. The melting is due to a dramatic reduction in upward heat flux at the soil surface caused by the increased thermal insulation of the snow cover, and the steady heat flux from the deeper $(>1 \mathrm{~m})$ soil layer. Since the heat flux is sensitive to thermal conductivity, accurate estimation of the soil and snow thermal conductivities is critical for quantitative understanding of the soil water dynamics under thick snow cover. This is particularly true for numerical simulation of the soil water, heat and dissolved mass transfer used to assess the impacts of climate change and snow management practices. Further research is required to improve the accuracy of measurements and model estimation of thermal conductivities.

\section{Acknowledgements}

We thank Shinji Suzuki for useful advice on soil thermal conductivity estimation, Kazunobu Kuwao for laboratory assistance; Manabu Nemoto for helpful suggestions; and Akira Yorisaki and Climatec Inc. for site instrumentation. The technical assistance of Norihiro Hirai and the Field Operation Section of National Agricultural Research Center for Hokkaido Region is also gratefully acknowledged. The study was partially funded by the Global Environment Research Coordination System Grant from the Japan Ministry of Environment and the Invitation Fellowship to MH from the Japan Society for Promotion of Science.

\section{References}

Bayard, D., Stähli, M., Parriaux, A., and Flühler, H., 2005: The influence of seasonally frozen soil on the snowmelt runoff at two Alpine sites in southern Switzerland, J. Hydrol., 309, 66-84.

Budavari, S. (ed.), 1996: The Merck index. 12th ed., Merck Publ. Group, Rathway, NJ, USA.

Decker, K. L. M., Wang, D., Waite, C., and Scherbatskoy, T., 2003: Snow removal and ambient air tempera- 
ture effects on forest soil temperatures in Northern Vermont, Soil Sci. Soc. Am. J., 67, 1234-1242.

Dorzey, N. E., 1940: Properties of ordinary water substances, Reinhold, New York, 673 pp.

Gray, D. M., and Granger, R. J., 1986: In situ measurement of moisture and salt movement in frozen soils, Can. J. Earth Sci., 23, 696-704.

Hardy, J. P., Groffman, P. M., Fitzhugh, R. D., Henry, K. S., Welman, A. T., Demers, J. D, Fahey, T. J., Driscoll, C. T., Tierney, G. L., and Nolan, S., 2001: Snow depth manipulation and its influence on soil frost and water dynamics in a northern hardwood forest, Biogeochemistry, 56, 151-174.

Hayashi, M., Goeller, N. T., Quinton, W. L. and Wright, N., 2007. A simple heat-conduction method for simulating the frost-table depth in hydrological models. Hydrol. Processes, 21, 2610-2622.

Hirota, T., Fukumoto, M., and Watanabe, T., 2001: In Report on the Meteorological Researches (Kisyoukenkyuu-note) Vol. 199 (ed. by Tsukamoto S. and Mozi N.). The Society of Agricultural Meteorology of Japan, pp. 141-151 (in Japanese).

Hirota, T., Iwata, Y., Hayashi, M., Suzuki, S., Hamasaki, T., Sameshima, R., and Takayabu, I., 2006: Decreasing soil-frost depth and its relation to climate change in Tokachi, Hokkaido, Japan, J. Meteorl. Soc. Jpn., 84, 821-833.

Horton, R., Wierenga, P. J., and Nielsen, D. R., 1983: Evaluation of methods for determining the apparent thermal diffusivity of soil near the surface, Soil Sci. Soc. Am. J., 47, 25-32.

Iwata, Y., and Hirota, T., 2005: Monitoring over-winter soil water dynamics in a freezing and snow-covered environment using a thermally insulated tensiometer, Hydrol. Processes, 19, 3013-3019.

Iwata, Y., Hayashi, M., and Hirota, T., 2008: Comparison of snowmelt infiltration under different soil-freezing conditions influenced by snow cover, Vadose Zone J., 7, 79-86.

Johansen, O., 1977: Thermal conductivity of soils, Cold Regions Research and Engineering Laboratory, pp. 177-223.

Kasubuchi, T., 1977: Thermal properties of soil, Soil Phys. Cond. Plant Growth Jpn., 35, 29-34 (in Japanese).

Noshiro, M., and Hirashima, T., 1978: Studies on freezing resistance of pasture species, J. Jpn. Grassl. Sci., 23, 289-294 (in Japanese with English abstract).

Oka, T., 2000: Geological features and it's explanation at Middle Tokachi Plain, Geol. Surv. of Hokkaido, Sapporo, Japan (in Japanese).

Sharratt, B., Benoit, G., Daniel, J., and Staricka, J., 1999: Snow cover, frost depth, and soil water across a prairie pothole landscape, Soil Sci., 164, 483-492.

Shimada, T., Shibata, S., and Masuyama, I., 1993: Meteorological factors responsible for winter injury of Orchardgrass, J. Jpn. Grassl. Sci., 39, 77-85.

Sturm, M., Holmgren, J., König, M., and Morris, K., 1997: The thermal conductivity of seasonal snow, $J$. Glaciology, 143, 26-41.

Thorud, D. B., and Duncan, D. P., 1972: Effects of snow removal, litter removal and soil compaction on soil freezing and thawing in a Minnesota Oak Stand, Soil Sci. Soc. Am. Proc., 36, 153-157.

Tsuchiya, F., 1985: Effect of soil frost and frost penetration on volcanic ash soil in agricultural field in Tokachi, eastern Hokkaido, Japan, Ph. D. thesis, Hokkaido Univ., Japan, 234 pp (in Japanese with English abstract).

Yamazaki, Y., Tsuchiya, F., and Tsuji O., 2003: Measurement and estimation of thermal conductivity of quartz-containing frozen and unfrozen soils, Trans. Jpn. Soc. Irrig. Drain., 226, 43-51 (in Japanese with English abstract).

\section{APPENDIX}

\section{Johansen (1977) model of soil thermal conductivity}

Normalized thermal conductivity (called the Kersten number; $K_{e}$ ) is defined as:

$$
K_{e}=\left(\lambda-\lambda_{d r y}\right) /\left(\lambda_{s a t}-\lambda_{d r y}\right)
$$

where $\lambda$ is thermal conductivity of the soil, $\lambda_{d r y}$ is thermal conductivity in the dry state, and $\lambda_{\text {sat }}$ is thermal conductivity in the saturate state.

The $\lambda_{d r y}\left(\mathrm{~W} \mathrm{~m}^{-1} \mathrm{~K}^{-1}\right)$ for natural soil is estimated by the following equation:

$$
\lambda_{d r y}=\left(0.135 \rho_{b}+64.7\right) /\left(\rho_{d}-0.947 \rho_{b}\right)
$$

where $\rho_{b}$ is soil dry bulk density and $\rho_{d}$ is the particle density of soil $\left(\mathrm{kg} \mathrm{m}^{-3}\right)$.

The $\lambda_{\text {sat }}$ is calculated as a geometric mean of the thermal conductivities of soil solids $\left(\lambda_{s}\right)$ and water $\left(\lambda_{w}=0.57 \mathrm{~W} \mathrm{~m}^{-1} \mathrm{~K}^{-1}\right)$ :

$$
\lambda_{s a t}=\lambda_{s}^{(1-n)} \lambda_{w}^{n}
$$


where $\mathrm{n}$ is porosity. The $\lambda_{s}$ is calculated by:

$$
\lambda_{s}=7.7^{q} \times 2.0^{(1-q)}
$$

where $\mathrm{q}$ is the volumetric content of quartz. The $\mathrm{K}_{e}$ of unfrozen soil is given by:

$$
K_{e}=\log \left(S_{r}\right)+1.0
$$

where $\mathrm{S}_{r}$ is water saturation of soil. Yamazaki et al. (2003) found that the $K_{e}$ of volcanic-ash soils was considerably larger than the values given by (A5), and modified (A5) as discussed in the text.

\title{
土壌凍結地带の農地において積雪層の厚さが土袞中の 熱フラックスと土壌水分の凍結・融解に与える影響
}

\author{
岩田幸良*・林 正貴 $* *$ ・廣田知良 * \\ $\left(\begin{array}{c}* \text { 北海道農業研究センター } \\ * * \text { カルガリー大学 }(\text { カナダ })\end{array}\right)$
}

要 約

積雪層は効果的な断熱材の役割をするため, 積雪層 の多少は寒冷圈における土兴の熱・水環境に大きな影響 を与える。土壌凍結が発達した戋場において積雪層の厚 さの変化に伴う農地環境の変化を評価するため, 北海道 の十勝地域に観測サイトを設置し，地温や雪温，土袞水 分量等の観測をおこなった。観測データから地表面，凍 結層下端, 深さ $95 \mathrm{~cm}$ の熱フラックスを計算し, 土壌水 の凍結・融解水量を計算した。その結果, $70 \mathrm{~cm}$ 以上の 積雪層の断熱効果によって地表面から積雪層に放出され る熱が減少し, 非積雪期間には土㙵中の熱収支にほとん
ど影響を与えない深さ $1 \mathrm{~m}$ 付近の熱フラックスと同等か, それ以下になることで凍結層の水が融解することが明ら かになった。一方, 熱収支法により今回推定した土㙵水 の凍結・融解量は推定䛊差が大きく, 積雪・土壌凍結 地帯の熱と土壌水分移動の関係を定量的に評価するため には雪と土壌の熱伝導率の正確な推定が必要であること が示唆された。

キーワード：土壌凍結, 凍土, 積雪層の断熱効果, 熱 伝導率, 土壤水分 